\title{
EFFECT OF HIGH TEMPERATURE ON COMPOSITE AS POST ENDODONTIC RESTORATION IN FORENSIC ANALYSIS-AN IN VITRO STUDY
}

\author{
Krishma Sharda $^{1}$, Varun Jindal ${ }^{2}$, Ajay Chhabra ${ }^{3}$, Damanpreet ${ }^{4}$, Dilpreet ${ }^{5}$ \\ ${ }^{1}$ Post Graduate student, Department of Conservative Dentistry \& Endodontics, Bhojia Dental College and Hospital, Baddi, Himachal Pradesh \\ ${ }^{2}$ Reader, Department of Conservative Dentistry \& Endodontics, Bhojia Dental College and Hospital, Baddi, Himachal Pradesh \\ ${ }^{3}$ Prof. and Head, Department of Conservative Dentistry \& Endodontics, Bhojia Dental College and Hospital, Baddi, Himachal Pradesh \\ ${ }^{4}$ Sr. Lecturer, Department of Conservative Dentistry \& Endodontics, Bhojia Dental College and Hospital, Baddi, Himachal Pradesh \\ ${ }^{5}$ Sr. Lecturer, Dept. of Conservative Dentistry \& Endodontics, Bhojia Dental College and Hospital, Baddi, Himachal Pradesh
}

Corresponding Author: Krishma Shard Mobile: +91-9816772674 E-mail: dr_kari2006@yahoo.co.in

\begin{abstract}
Aim: The present study was done to evaluate and compare the effect of different temperatures $\left(400^{\circ} \mathrm{C}, 800^{\circ} \mathrm{C}\right.$ and $1000^{\circ} \mathrm{C}$ ) on Composite as post endodontic restoration using Naked eye, Digital camera and Radiovisiography (RVG) in forensic analysis. Methodology: An in vitro study was conducted on 42 human teeth with composite as post endodontic restoration exposed to three temperature ranges: $400^{\circ} \mathrm{C}, 800^{\circ} \mathrm{C}$ and $1,000^{\circ} \mathrm{C}$. Results: Composite material studied in the present research offered great resistance to high temperatures, without exhibiting considerable macrostructure variation, in such a way that physical changes (dimensional stability, fissures, cracks, fractures, texture, color, carbonization and incineration) can be identified and associated to each specific temperature range. Conclusion: Dental tissues and materials offer great resistance to the effect of high temperatures. Moreover, they present specific changes (color, texture, fissures, cracks fractures, fragmentation) which might contribute to the process of identifying a corpse, or burned, incinerated or carbonized human remains.
\end{abstract}

Key words: Composite, Forensic analysis, Incineration.

\section{INTRODUCTION}

The dentition represents one of the most resilient structures in the human body and can survive extreme conditions. Destruction of a body by various meansfire, desiccation, decomposition, prolonged water immersion-can make it unrecognizable, while teeth-the most indestructible components of the human body-may continue to provide a method for positive personal identification. ${ }^{2}$

Human identification by forensic odontological analysis is a wellestablished and reliable method. ${ }^{3}$ Dental identification plays a major role in the identification of corpses with postmortem alterations such as advanced stages of putrefaction or burning, mass casualties either from natural disasters or due to armed conflicts. ${ }^{4}$ Dental antemortem/ postmortem comparison by odontologists continues to be the major scientific method for identification ${ }^{5,6}$ and radiographic images of dental structures are utilized in image comparison to support odontologist's conclusions. ${ }^{3}$

Fire remains one of the major causes of morbidity and mortality throughout world. Knowledge of the mechanical properties of teeth and dental materials commonly used in restorations following exposure to high temperatures can prevent unintentional destruction of the evidence as well as increase the chances of a positive identification. ${ }^{2}$

Some dental materials like amalgam have already been studied with regard to their resistance to high temperatures. However, in modern dentistry, the placement of 
amalgam restorations is dwindling with $30 \%$ decrease in the use of amalgam in last 10 years. This direction will inevitably continue as patients become increasingly esthetic conscious and preferring composite resins even for posterior placement. ${ }^{1}$ There is not much information in the literature about the effects of high temperatures on composite resins, however. $^{8}$

Most of the features of damage to the oral tissues and dental restorations can be observed directly by the naked eye but additional microscopic investigation, either optical or electronic, is very useful in studying the finer details of the dental tissues and any distinguishing traits in the restorative materials present. $^{9}$

India is a disaster prone country with an average of eight major natural calamities a year. During all these disasters the bodies of most of the victims are mutilated beyond recognition by visual or any other methods. Under these situations forensic dental identification is extremely valuable. ${ }^{10}$ It is thus necessary to conduct new studies using different kinds of analysis which would explain the macrostructural changes based on the microstructural ones; accordingly, it would be appropriate to analyze the behaviour of the materials of dental use.

\section{MATERIALS AND METHOD}

A total of 42 extracted non-carious single rooted intact teeth were collected from the Department of Oral and Maxillofacial Surgery, Bhojia Dental College and Hospital, Baddi. After the extraction, the teeth were washed with Normal saline in order to eliminate blood deposits, and were placed in a fixing solution 5\% Chloramine T (100 grams of sodium Tosilcloramine diluted in 2 liters of water) for a week. The teeth were then stored in a saline solution which was changed every two weeks until the procedure was initiated.

An access opening was prepared using a round bur and Endo $\mathrm{Z}$ bur and the canal patency was checked using No. $10 \mathrm{~K}$ file. Then the working length was determined by substracting $1 \mathrm{~mm}$ from where the No. $10 \mathrm{~K}$ file protruded from the apical foramen. The biomechanical preparation was done using the hybrid technique. The glide path was prepared using hand file (no $15 \mathrm{~K}$ file). Then the canal was prepared in crown-down approach using hyflex rotary file system and the canal was irrigated copiously using 5.25\% sodium hypochlorite and normal saline and recapitulated regularly. The apical enlargement was done till No $40 \mathrm{~K}$ file. Now, all teeth were obturated using lateral condensation obturation technique using conventional gutta percha cones and zinc oxide eugenol as sealer and post endodontic restoration was done with composite. Then the teeth were randomly divided into three groups and were subjected to three different temperatures (14 teeth at each temperature):

Group A. $400^{\circ} \mathrm{C}$

Group B. $800^{\circ} \mathrm{C}$ and

Group C. $1000^{\circ} \mathrm{C}$

Now, the radiographs and preincineration images of all the samples were taken. Teeth of a specific subgroup were placed in a ceramic crucible and subjected for 15 mins to temperatures of $400^{\circ} \mathrm{C}, 800^{\circ} \mathrm{C}$ and $1000^{\circ} \mathrm{C}$ in a burn out oven. Once the target temperature was reached, the teeth were removed from the furnace. While the teeth were cooling down, they were sprayed with hairspray in order to provide them with some level of resistance and to facilitate their handling. Again, after incineration post-incineration radiographs and images were taken.

The incinerated material was then examined for the changes and resistance to temperature using Naked eye examination, digital camera and RVG for forensic analysis.

\section{OBSERVATIONS AND RESULTS}

Results derived from the study are tabulated as follows: 

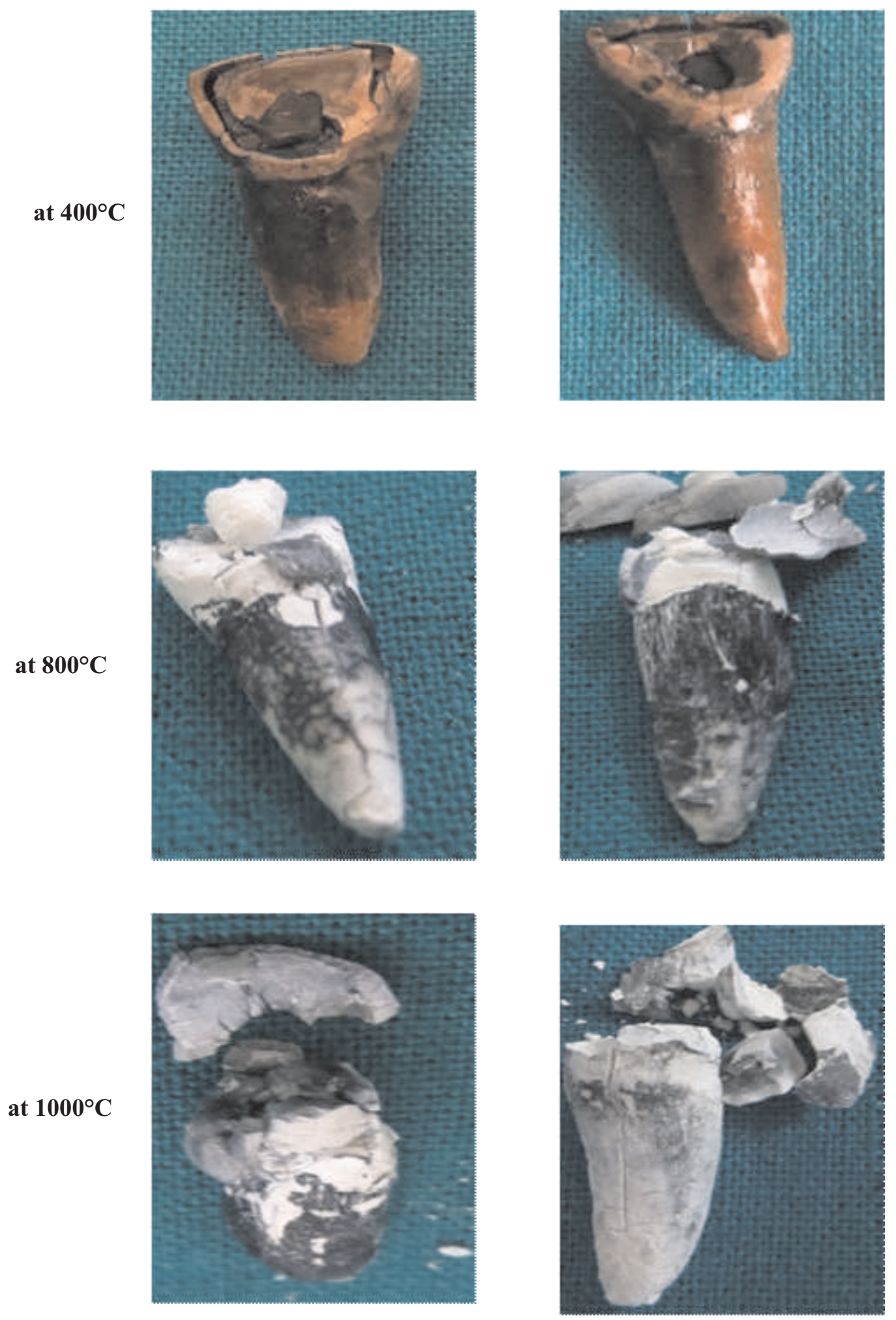

Figure 1: Digital Camera evaluation of the samples at different temperatures 


\section{at $400^{\circ} \mathrm{C}$}
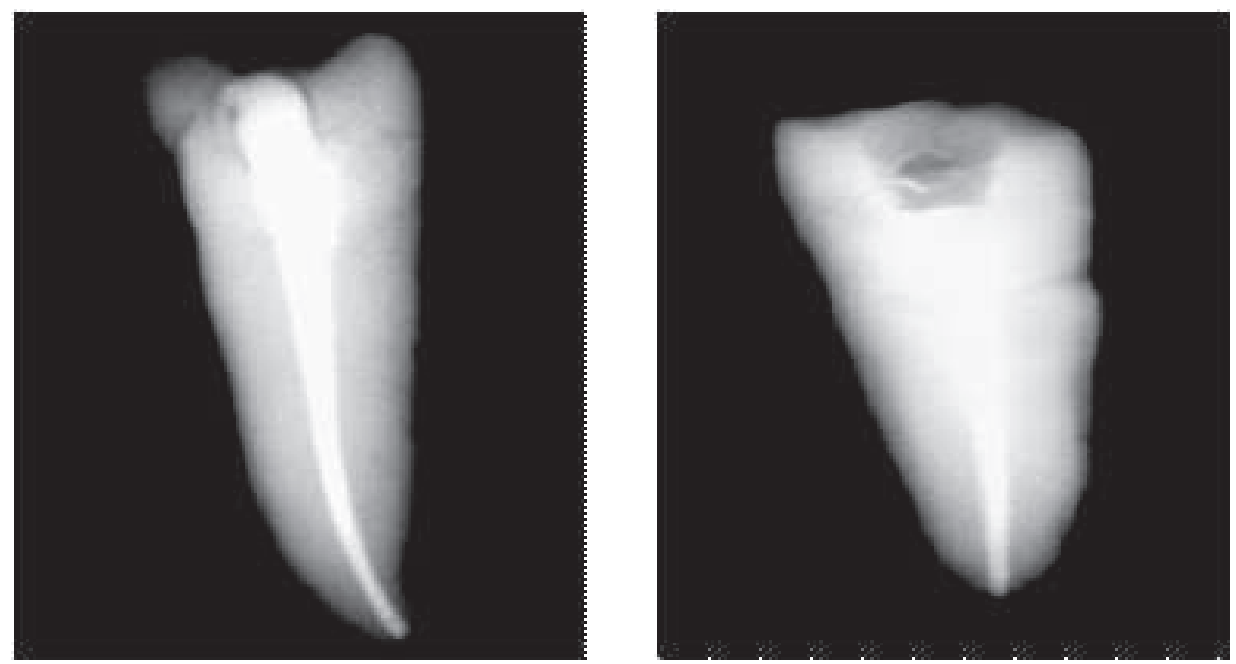

at $800^{\circ} \mathrm{C}$
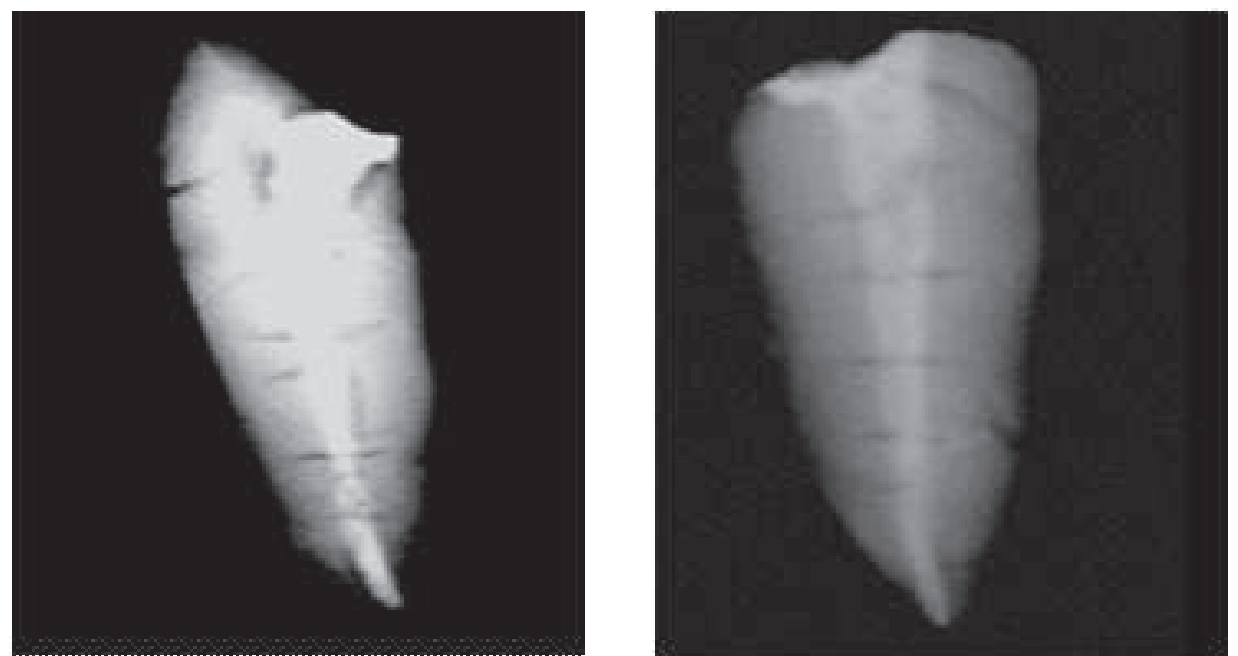

at $1000^{\circ} \mathrm{C}$
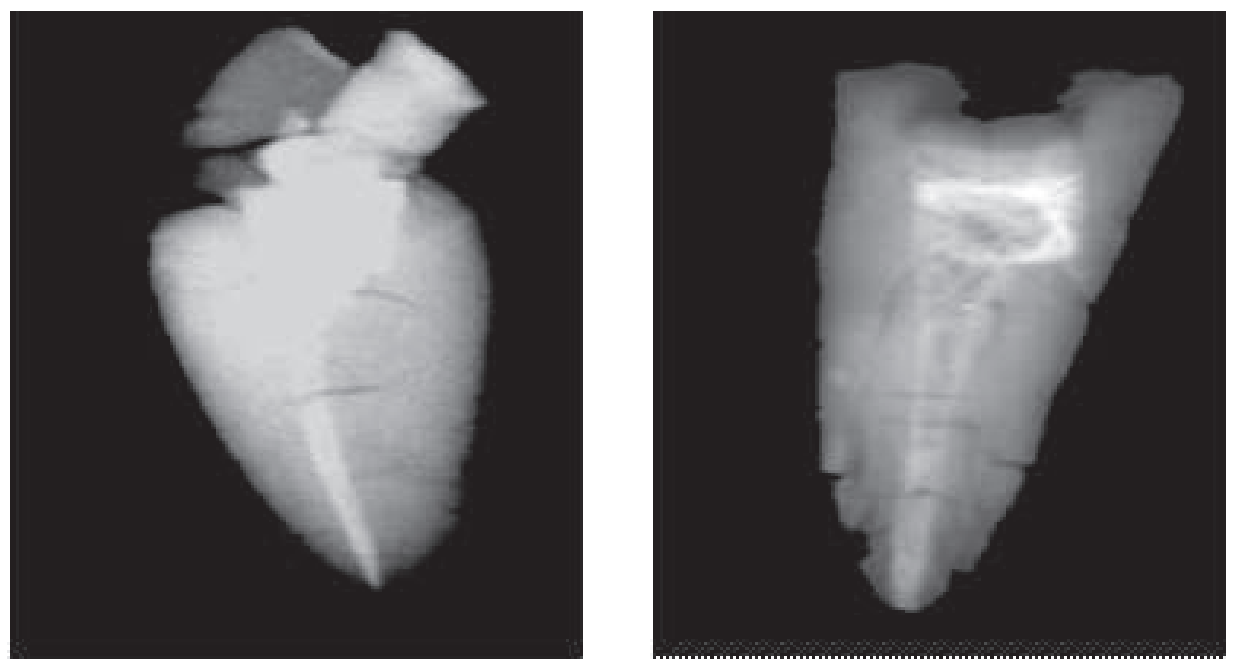

Figure 2: Radiovisiography of the samples at different ranges 


\begin{tabular}{|c|c|c|c|}
\hline $\begin{array}{l}\text { Temperature } \\
\text { Group } \mathrm{A} \\
\left(\text { at } 400^{\circ} \mathrm{C}\right)\end{array}$ & $\begin{array}{l}\text { Naked Eye Evaluation } \\
\text { The crown of the samples } \\
\text { were intact but had } \\
\text { horizontal and vertical } \\
\text { fracture lines on them. } \\
\text { Only in one sample a } \\
\text { portion of coronal tooth } \\
\text { structure was lost. There } \\
\text { was evident change in } \\
\text { color of the teeth ranging } \\
\text { from light to dark brown, } \\
\text { while the composite } \\
\text { restorations had dark } \\
\text { brown color. The } \\
\text { composite restorations } \\
\text { although remaining whole } \\
\text { had undergone marginal } \\
\text { retraction. }\end{array}$ & $\begin{array}{l}\text { Digital Cam era Evaluation } \\
\text { The teeth were intact and } \\
\text { except in one sample } \\
\text { which had coronal portion } \\
\text { fractured and detached. } \\
\text { There were fracture lines } \\
\text { on the crown portion of } \\
\text { the teeth. The composite } \\
\text { restorations turned to dark } \\
\text { brown and presented } \\
\text { marginal maladaptation as } \\
\text { well as superficial cracks } \\
\text { and fissures. }\end{array}$ & $\begin{array}{l}\text { Radiovisiography } \\
\text { The teeth showed } \\
\text { fracture lines. } \\
\text { Composite restorations } \\
\text { were observed as } \\
\text { radiopaque. They were } \\
\text { intact but showed } \\
\text { marginal retraction }\end{array}$ \\
\hline $\begin{array}{l}\text { Group B } \\
\left(\text { at } 800^{\circ} \mathrm{C}\right)\end{array}$ & $\begin{array}{l}\text { The crowns of the teeth } \\
\text { had shattered into pieces } \\
\text { whereas root remained as } \\
\text { whole. The surface color } \\
\text { of the teeth was chalky } \\
\text { white while its interior } \\
\text { was blue-grey. There were } \\
\text { cracks in the roots but the } \\
\text { composite restorations } \\
\text { were in place. Composite } \\
\text { restorations were chalky } \\
\text { white. Even though the } \\
\text { restorations maintained } \\
\text { their shape, they showed } \\
\text { marginal retraction. }\end{array}$ & $\begin{array}{l}\text { The color of the root } \\
\text { surfaces was bluish grey } \\
\text { with chalky white patches. } \\
\text { The crowns and } \\
\text { composite restorations } \\
\text { were chalky white. There } \\
\text { was cracking and } \\
\text { separation between } \\
\text { enamel and dentine as } \\
\text { well as between dentine } \\
\text { and fillings, while the } \\
\text { roots remained intact with } \\
\text { deep cracks. }\end{array}$ & $\begin{array}{l}\text { The crowns were } \\
\text { disintegrated. There } \\
\text { were deep cracks on } \\
\text { the teeth. The } \\
\text { composite restorations } \\
\text { were observed as } \\
\text { radiopaque with } \\
\text { altered shape and } \\
\text { marginal retraction. }\end{array}$ \\
\hline $\begin{array}{l}\text { Group C } \\
\left.\text { ( at } 1000^{\circ} \mathrm{C}\right)\end{array}$ & $\begin{array}{l}\text { The crowns had shattered } \\
\text { and after handling the } \\
\text { crown disintegrated } \\
\text { completely while the roots } \\
\text { were intact with greyish } \\
\text { white color. There were } \\
\text { numerous deep cracks and } \\
\text { microfractures on the } \\
\text { remaining tooth structure. } \\
\text { The composite } \\
\text { restorations were totally } \\
\text { dislodged due to } \\
\text { fragmentation of the } \\
\text { crown. }\end{array}$ & $\begin{array}{l}\text { The sample fractured into } \\
\text { chalky white and grey } \\
\text { fragments. The root } \\
\text { surface showed fracture } \\
\text { lines. The composite } \\
\text { restorations } \\
\text { dislodged and severely } \\
\text { altered in shape and } \\
\text { displayed white color. }\end{array}$ & $\begin{array}{l}\text { The crowns were } \\
\text { totally shattered with } \\
\text { radiolucent fracture } \\
\text { lines in the remaining } \\
\text { tooth structure. The } \\
\text { radiopaque composite } \\
\text { restorations had } \\
\text { dislodged due to } \\
\text { shattering of the crown } \\
\text { hence could not be } \\
\text { differentiated at this } \\
\text { temperature in the } \\
\text { radiograph. Few } \\
\text { samples had composite } \\
\text { restoration in place but } \\
\text { they showed great } \\
\text { alteration in shape. }\end{array}$ \\
\hline
\end{tabular}




\section{DISCUSSION}

Determining the identity of a victim that has sustained extensive damage to the tissues because of burning is a challenging task. ${ }^{11}$ Usually, dentists are called upon to assist in the identification processes of burned victims, in cases where there is extensive tissue destruction, and subjects cannot be identified through conventional means, digital recognition or fingerprints. ${ }^{12}$ The most usual matching process is conducted based upon dental treatment such as prosthetic restorations and dental fillings, distinctive osseous and dental morphological traits, distinctive pathological variations and DNA collection from dental pulp not affected by high temperatures. ${ }^{13}$

Describing physical macro-structural changes which take place in tissues and dental materials used in conventional dental treatment when subjected to high temperature could assist in the assessment of incinerated, carbonized or burned human remains and thus determine which dental treatments existed as well as dental materials with which they were conducted. This enables to scientifically establish reliable identification of a subject or its remains. ${ }^{12}$ The present study has evaluated the effect of high temperature on composite as post endodontic restorations in forensic analysis.

Nowadays, with new advances the placement of amalgam restorations is diminishing due to the controversies related its use. This decrease has been increasing with time because now the patients are becoming more aware and esthetically more conscious, so the dentists respond to the trend by offering more natural-appearing restorations. Tooth colored resins are used under most circumstances, even for posterior placement. ${ }^{1}$ However, this group of restorative materials may be more susceptible to physical changes resulting from higher temperatures than traditional amalgam restorations. Because of fundamental differences among components used in this material class, the response of these materials to varying levels of heat may differ significantly. Such differences may be used as an aid in the identification of the exact type of restoration present in an unidentified person.

In this study, in all the teeth fissures or superficial cracks were observed at $400^{\circ} \mathrm{C}$, which turned into deep cracks to fracture lines at $800^{\circ} \mathrm{C}$ followed by fragmentation of crown portion of teeth at $800^{\circ} \mathrm{C}$ to $1000^{\circ} \mathrm{C}$ (Figure 1). The teeth got disintegrated when handled at $1000^{\circ} \mathrm{C}$. These findings were similar to as described by Gunther and Schdmit. ${ }^{14}$ There were longitudinal cracks in the root dentine which coincide with the description by Nossintchou. ${ }^{14}$ This highlights two important points: first, that calcined teeth, being completely dehydrated, are very delicate, and secondly, that fractures may procede the fire because in real life situations trauma is often associated with the high temperatures caused by major fires.

While dealing with composite resin, the fact that draws attention is the change in color. ${ }^{12}$ In the present study at $400^{\circ} \mathrm{C}$, the composite restoration turned to brown hue and presented mild marginal retraction as well as superficial cracks and fissures which was due to the acrylic matrix combustion and is in concurrence with the study conducted by Vazquez $\mathrm{L}$ et $\mathrm{al}^{12}$ and Moreno $\mathrm{S}$ et $\mathrm{al}^{14}$. The marginal contraction apparent in the composite restoration is probably due to the loss of the organic matrix as described by Moreno $\mathrm{S}$ et $\mathrm{al}^{14}$. The resin restoration on a digital radiograph appeared to be intact and could be easily identified. Marginal retraction between the restoration and tooth structure was observed on the radiograph.

In this study, at $800^{\circ} \mathrm{C}$ detachment and macroscopic shattering of the crown was seen which was also observed by Merlati G, Danesino P et al (Figure 2). ${ }^{15}$ The crown was dark gray to grayish black in color while the color of the root surface was chalky white. There were cracks in the root. In most of the samples there was dislodgement of the fillings which was also perceived by Moreno $\mathrm{S}$ et al. $^{14}$ The marginal maladaptation between the tooth structure and the resin restoration was observed on the radiograph. Savio $\mathrm{C}$ et $\mathrm{al}^{16}$ also observed dislodged coronal composite restoration radiographically in most of the samples that comply with the radiographic findings of the present study.

When the teeth were subjected to $1000^{\circ} \mathrm{C}$ they showed that in majority of the samples crowns were cracked and shattered at this temperature and deep cracks developed in the root. Also the restorations were totally dislodged from the cavity due to fragmentation of the crown. This is similar to the findings by Vazquez $\mathrm{L}$ et $\mathrm{al}^{12}$ and Merlati G, Danesino P et al. ${ }^{15}$ Most of the specimen broke at first touch as also perceived by Merlati G, Savio C et al. ${ }^{17}$ The composite material was difficult to detect, if observed it displayed severely altered shape and a white color. Because of the dislodged restoration and shattering of the crown, the composite restoration could not be differentiated on 
the radiograph at this temperature which is in accordance with the findings by Savio C et al. ${ }^{16}$

In the present study, once the pre-determined temperatures were reached, the samples were removed from the oven and allowed to cool at room temperature. The materials were therefore subjected to only one controlled and limited thermal shock. In reality many factors may further complicate the effect of the fire on the tissues and materials such as time of exposure to the fire, the type of fire, the speed of increase in temperature as well as the substances used to extinguish the fire. All of these factors need to be considered in evaluating the specimens for forensic analysis

\section{Conclusion}

Within the limits of this experimental research, the study has shown that composite may provide a source of forensic evidence after exposure to temperatures of up to $1000^{\circ} \mathrm{C}$, indicating that this material can be used as means of comparison in human identification even in high temperature fire victims.

The comparison of ante and post mortem radiographs prove to be essential aid in forensic analysis. Therefore, the importance of maintenance of detailed dental records should be re-emphasized. Every dentist should make an effort to maintain comprehensive and elaborate dental records of patients. This will ensure the use of restorations recovered from a burn scene in post-mortem identification. Only then, will the field of forensic dentistry be able to gain a foothold in forensic investigations in India.

\section{REFERENCES}

1. Bush MA, Prutsman-Pfeifer J, Miller RG et al. Identification through X-Ray fluorescence analysis of dental restorative resin materials: A comprehensive study of noncremated, cremated and processed-cremated individuals. J Forensic Sci 2007;52:157-65.

2. Brandao R.B, Martin C. C.S., Catirse Alma B.C.E.B. et al. Heat Induced Changes to Dental Resin Composites: A Reference in Forensic Investigations? J Forensic Sci, 2007
July;52(4)

3. Rothwell BR. Principles of dental identification. Dent Clin North Am 2001 Apr;45:253-269.

4. James H. Thai tsunami victim identification overview to date. J Forensic Odontostomatol. 2005;23:1-18

5. Valenzuela A, Heras S. M-de 1, Marques $T$ et al. The application of dental methods of identification to human burn victims in a mass disaster. Int. J. Legal Med. 2000;113(4):236-239.

6. Hutt J.M, Ludes B, Kaess A et al. Odontological identification of the victims of flight AI.IT 5148 air disaster Lyon-Strasbourg 20.01.1992. Int. J. Legal Med. 1995; 107:275-279.

7. Lonnermark A, Ingason H. Gas temperatures in heavy goods vehicle fires in tunnels, Fire Safety J. 2005;40:506-527.

8. Bush MA, Miller RG, Norrlander AL et al. Analytical survey of restorative resins by SEM/EDS and XRF:databeses for forensic purposes. J Forensic Sci 2008 Mar;53(2):419-425.

9. Bonavilla JD, Bush MA, Bush PJ et al. Identification of Incinerated Root Canal Filling Materials after Exposure to High Heat Incineration. J Forensic Sci, 2008 Mar;53(2):41218.

10. Park K. Park's textbook of Preventive and social medicine. 17th ed. Jabalpur (India), p. 568-573.

11. Bush MA, Bush PJ, Miller RG. Detection and classification of composite resins in incinerated teeth for forensic purposes. J Forensic Sci. 2006 May;51(3):636-642.

12. Vazquez L, Rodriguez P, Moreno F. In vitro macroscopic analysis of dental tissues and some dental materials used in endodontics, submitted to high temperatures for forensic applications. Revista Odontologica Mexicana,2012 ; 16(3):171- 181.

13. Pretty IA, Sweet D. A look at forensic dentistry-Part 1: The role of teeth in the determination of human identity. Br Dental J 2001;190(7):359-366.

14. Moreno S, Merlati G, Marin L et al. Effects of high temperatures on different dental restorative systems: experimental study to aid identification process. J Forensic Dent Sci. 2009;1(1):17-23.

15. Merlati G, Danesino P, Savio C et al. Observations on dental prostheses and restorations subjected to high temperatures: Experimental studies to aid identification processes. J Forensic Odontostomatol 2002; 20(2);17-24.

16. Savio C, Danesino P, Merlati G et al. Radiographic evaluation of teeth subjected to high temperatures: Experimental study to aid identification processes. Forensic Sci. Int., 2006:108116.

17. Merlati G, Savio C, Danesino P et al. Further study of restored and un-restored teeth subjected to high temperatures. J Forensic Odonto-Stomatology 2004;22(2):34-39. 